\title{
PENGEMBANGAN PERANGKAT PEMBELAJARAN IPA DENGAN TAMPILAN MACROMEDIA FLASH DI SMP
}

\author{
Alfina Citrasukmawati, S.Pd ${ }^{1)}$ \\ Dr. Rahardjo, M.Si ${ }^{2)}$ \\ Prof. Dr. dr. Tjandrakirana, M.S., Sp.And ${ }^{3)}$ \\ 1)Mahasiswa Pascasarjana Prodi Pendidikan Sains Universitas Negeri Surabaya \\ 2)Dosen Pascasarjana Prodi Pendidikan Sains Universitas Negeri Surabaya \\ 3) Dosen Pascasarjana Prodi Pendidikan Sains Universitas Negeri Surabaya \\ e-mail : Alfinacitra@gmail.com
}

\begin{abstract}
Abstrac: The topic Nutrition and Energy Transformation concepts are abstract and difficult to comprehend. To overcome such a difficulty, it is necessary to develop a set of instructional package incorporating Macromedia flash. The Dick and Carey instructional development model was used for that purpose. Before the implementation of the instructional programs, all of the components of the instructional package consisted of lesson implementation plan, media, student worksheet Guided discovery type, student workbook, and assesment intrument, were validated and met the prescribed criteria. Implementation in the school only observe one class without replication. Thirty Junior High School Students involvedin this investigation using One Group Pretest-Postest Design. Result of this research shows the lesson plan is good (3,5), learning modul is good (3,0), student worksheet type Guided discovery is good (3,5), media is good (3,5), and student achievement mastery also good (3,0). Implementation lesson plan in class using direct instruction is good (3,67), with reliability around $82 \%$ (good/reliable). Student activity commonly is good $(13,25)$ with reliable average 92\%. Student respon is good, above 83\%. Student achievement increase with Gain score above 0.7. The result of observation of the teaching and learning process, conducted during its implementation, showed that there was a consistency between the prescribed teaching and learning experienced with its implementation. Students had met the $80 \%$ minimum mastery criteria. So it can be concluded that the development instructional package is effective to increase the junior High School student achievement.
\end{abstract}

Key Word: Macromedia flash, Guided discovery.

Abstrak: Materi proses perolehan nutrisi dan transformasi energi pada tumbuhan hijau sulit dipahami oleh siswa karena bersifat abstrak, sehingga tidak dapat dilihat secara nyata. Atas dasar itu, perlu kiranya mengembangkan perangkat pembelajaran dengan bantuan tampilan media Macro flash. Untuk itu, telah dilakukan suatu penelitian pengembangan perangkat pembelajaran, yang berorientasi Dick and Carey dan bertujuan meningkatkan hasil belajar siswa. Penelitian ini hanya dilakukan pada satu kelas saja, tanpa melakukan ulangan. Subyek penelitian 30 orang siswa kelas VIII SMP Negeri 22 Surabaya, dengan rancangan Short Case Pretest-Postest, sedangkan analisis data dilakukan secara deskriptif kualitatif. Hasil penilaian RPP baik (3,5), BAS baik (3,0), LKS bercirikan Guided discovery baik (3,5), media baik $(3,5)$ dan tes hasil belajar baik $(3,0)$. Pengelolaan pelaksanaan di kelas dengan pembelajaran langsung termasuk baik $(3,67)$ dengan reliabilitas $82 \%$ (baik/reliabel). Aktivitas siswa secara umum baik $(13,25)$ dengan reliabilitas rata-rata 92\%. Respon siswa secara umum tertarik sebesar $83 \%$ lebih. Tes hasil belajar menunjukan peningkatan tinggi dengan Gain score diatas 0,7. Simpulan penelitian menunjukkan bahwa pengembangan perangkat pembelajaran biologi berbasis Macromedia flash di SMP, layak digunakan, keterlaksanaan pembelajaran, aktivitas dan respon siswa baik, serta dapat meningkatkan hasil belajar siswa.

Kata kunci: Macromedia flash, Guided discovery.

\section{Pendahuluan}

Kesulitan belajar pada siswa dapat muncul karena banyak faktor, antara lain sarana dan prasarana, termasuk pula guru, siswa, materi, dan lain-lain. Siswa sekolah usia pendidikan menengah termasuk golongan berpikir konkrit, tetapi pembelajaran di sekolah sudah mulai mempelajari materi-materi yang bersifat abstrak. Diharapkan penggunaan media dapat membantu siswa usia tersebut memahami konsep-konsep yang sedang diajarkan.

Proses fotosintesis tumbuhan, difusi dan osmosis, serta respirasi yang sedang berlangsung kejadianya tidak dapat dilihat secara langsung oleh mata, sehingga penggunaan bantuan media mungkin dapat membuat informasi yang abstrak tadi, dapat direpresentasikan dengan baik sehingga konsep yang abstrak menjadi lebih konkret.
Meningkatkan hasil pembelajaran sains, guru dituntut lebih profesional mempersiapkan perangkat pembelajaran agar sesuai dengan kondisi dan keadaan lingkungan siswa, sehingga materi pelajaran mudah dipahami oleh para siswa. Pengalaman dapat berupa pengalaman langsung dan tidak langsung. Pengalaman langsung adalah pengalaman yang diperoleh melalui aktivitas sendiri pada situasi sebenarnya. Pengalaman tidak langsung, merupakan pengalaman yang diperoleh siswa melalui aktivitas tiruan sebagaimana aslinya. Alat yang dapat membantu proses belajar mengajar untuk memperoleh pengalaman tidak langsung ini yang dapat dikatakan sebagai media.

Sutopo (2003:60) mengemukakan media pembelajaran yang dapat memberikan pengalaman belajar lebih konkrit melalui penyajian audiovisual adalah Macromedia flash. Software tersebut mempunyai banyak kelebihan seperti 
tampilan gambar, animasi, dan suara yang dapat dibuat sekreatif mungkin sehingga menjadi daya tarik tersendiri untuk siswa.

Kelebihan Macromedia flash dapat digunakan untuk membantu berlangsungnya pembelajaran biologi dalam kelas, khususnya pada penyampaian materi-materi yang prosesnya tidak dapat dilihat langsung oleh siswa. Kerumitan bahan pembelajaran dapat disederhanakan dengan bantuan media tersebut, yang disampaikan dengan menggunakan Direct Intruction (pembelajaran langsung). Praktikum dilaksanakan untuk membantu penyampaian Lembar Kerja Siswa yang bercirikan Guided discovery.

Menurut Arends (2007:301), model pengajaran langsung dapat diterapkan pada mata pelajaran apapun. Model ini juga cocok untuk komponen-komponen mata pelajaran yang berorientasi-informasi seperti sains. Melengkapi proses belajar tadi, siswa diberikan Lembar Kerja Siswa yang bercirikan pembelajaran terbimbing (Guided Discovery).

Pembelajaran yang bercirikan penemuan terbimbing, mencoba membantu siswa mempelajari bagaimana belajar yang efektif dan efisien, dengan cara sedemikian itu siswa diberikan kesempatan untuk memperoleh dan membangun konsepsinya sendiri, dan membiasakan diri untuk menemukan sendiri informasi dan konsep yang dipelajarinya. Dari paparan di atas, dilakukan penelitian untuk mengetahui efektivitas perangkat pembelajaran IPA dengan tampilan media Macro flash di SMP.

\section{Metode Penelitian}

Penelitian ini merupakan penelitian pengembangan, pengembangan yang dimaksud adalah pengembangan perangkat pembelajaran yang dikembangkan dengan desain Dick and Carey yang telah dimodifikasi sesuai kebutuhan di lapangan.

Pada tahap pembuatan perangkat pembelajaran, disusun perangkat berupa Rencana Pelaksanaan Pembelajaran (RPP), Media Macro flash, Lembar Kegiatan Siswa (LKS) Guided discovery, Buku Ajar Siswa (BAS), dan Tes hasil belajar, yang selanjutnya perangkat tersebut divalidasi oleh 2 pakar ahli. RPP dikembangkan sesuai sintaks Direct Instruction yang telah dimodifikasi. Tahap pengembangan dilakukan dengan memperbaiki perangkat pembelajaran sesuai saran validator serta hasil ujicoba terbatas. Perangkat yang telah diperbaiki kemudian diujicobakan pada kelas yang telah tentukan.

Perangkat yang telah dibuat diujicobakan dengan desain one group pretest and posttest design. Ujicoba perangkat dilakukan di SMPN 22 Surabaya. Ujicoba dilakukan untuk memperoleh informasi efektivitas perangkat pembelajaran berupa keterlaksanaan, aktivitas siswa, hasil belajar siswa, dan respons siswa. Instrumen ujicoba berupa lembar pengamatan keterlaksanaan pembelajaran, lembar pengamatan aktivitas siswa, lembar tes hasil belajar, dan lembar respons siswa.

Hasil belajar siswa peningkatanya dapat diketahui melalui analisis $\mathrm{N}$-gain score dengan rumus sebagai berikut:

$$
(\mathrm{g})=\frac{(\text { Spost })-(\text { Spre })}{100 \%-(\text { Spre })}
$$

dengan $(\mathrm{g})=$ nilai gain, Spost $=$ nilai post-test, Spre $=$ nilai pre-test dan Smax = nilai maksimal. Dari hasil uji $N$ gain diketahui jika (g) $\geq 0,7$ maka peningkatanya masuk kategori tinggi, jika 0,7 > (g) $\geq 0,3$ kategori sedang, dan jika $(\mathrm{g})<0,3$ kategori rendah.

\section{hasil Penelitian dan Pembahasan}

Penelitian dilakukan diawali dengan pengembangan dan implementasi perangkat pembelajaran yang terdiri dari RPP, BAS, LKS, media dengan Macromedia Flash, dan THB. Hasil implementasi disajikan berikut ini:

\section{Keterlaksanaan Rencana Pelaksanaan} Pembelajaran (RPP)

Tabel 4.6 Hasil Pengamatan Keterlaksanaan RPP

\begin{tabular}{|c|c|c|c|}
\hline No & Aspek yang Diamati & Rerata & Kategori \\
\hline I & Pengelolaan KBM & & \\
\hline \multirow[t]{2}{*}{ A } & PENDAHULUAN & & \\
\hline & $\begin{array}{l}\text { Fase 1: menyampaikan } \\
\text { tujuan dan memotivasi } \\
\text { siswa }\end{array}$ & 3.5 & Baik \\
\hline \multirow[t]{5}{*}{$\mathrm{B}$} & KEGIATAN INTI & & Baik \\
\hline & $\begin{array}{c}\text { Fase 2: } \\
\text { Mendemonstrasikan } \\
\text { Pengetahuan }\end{array}$ & 4 & Baik \\
\hline & $\begin{array}{c}\text { Fase 3. Memberi Latihan } \\
\text { Terbimbing. }\end{array}$ & 3.6 & Baik \\
\hline & $\begin{array}{l}\text { Fase 4: Mengecek } \\
\text { pemahaman dan } \\
\text { memberi umpan balik }\end{array}$ & 3.3 & Baik \\
\hline & $\begin{array}{l}\text { Fase 5: Memberikan } \\
\text { latihan lanjutan }\end{array}$ & 3.2 & Baik \\
\hline $\mathrm{C}$ & PENUTUP & & \\
\hline
\end{tabular}

Pendapat Nur (2008:78) menyatakan bahwa salah satu faktor yang mempengaruhi kualitas pembelajaran adalah tersedianya perangkat pembelajaran yang disertai dengan komitmen yang tinggi untuk menggunakannya dalam setiap pembelajaran. Terlaksananya kegiatan belajar mengajar karena guru dalam proses pembelajaran memiliki komitmen yang tinggi untuk menggunakan perangkat pembelajaran yang telah dikembangkan. Suatu program pembelajaran akan dapat mencapai hasil seperti yang diharapkan apabila direncanakan dengan baik.

Sesuai pendapat (Sagala, 2008:46) bahwa semua komponen pengajaran harus diperankan secara optimal 
guna mencapai tujuan pengajaran yang telah dirumuskan sebelum pengajaran dilaksanakan. Agar proses pembelajaran berlangsung dengan baik, maka guru harus merancang pembelajaran yang akan dilaksanakan, terutama untuk menentukan langkah-langkah pembelajaran yang sesuai dengan karakteristik materi yang akan diajarkan dan membuat indikator untuk mengetahui apakah pembelajaran yang telah dirancang dapat berjalan dengan efektif atau tidak. Rencana pelaksanaan pembelajaran adalah panduan langkahlangkah yang akan dilakukan oleh guru dalam kegiatan pembelajaran yang disusun dalam skenario (Sagala, 2008:71).

Hasil penelitian berdasarkan terlihat bahwa aspek pemberian motivasi memperoleh skor rata-rata 3.7 yang berarti baik. Aspek pengkomunikasian tujuan pembelajaran oleh guru mendapat skor rata-rata 3 yang berarti baik. Aspek penyajian informasi dengan media Macro flash, dan mengintruksikan siswa untuk mengerjakan LKS bercirikan Guided discovery, masingmasing memperoleh skor rata-rata 4 yang berarti baik. Aspek memberikan penjelasan tentang cara praktikum dan mengerjakan soal dalam LKS memperoleh skor rata-rata 3.8 yang berarti baik. Fase empat pada aspek memberikan balikan dan mengecek pemahaman siswa memperoleh skor rata-rata 3.5 yang berarti baik. Aspek membimbing siswa untuk membuat rangkuman, masing-masing memperoleh skor rata-rata 3.3 yang berarti cukup baik. Aspek menyimpulkan materi yang telah dipelajari, memperoleh skor rata-rata 3.2 yang berarti cukup baik. Hal ini menunjukkan bahwa rata-rata kemampuan guru (peneliti) dalam melaksanakan pembelajaran pada uji coba yang meliputi lima aspek termasuk kegiatan pendahuluan, kegiatan inti, kegiatan penutup, dinilai terlaksana dengan baik, sesuai dengan sintaks pembelajaran pembelajaran langsung yang telah dirancang pada rencana pembelajaran, dapat terlihat pada persentase keterlaksanaan pembelajaran yang mendapat penilaian baik.

Dua aspek mendapatkan skor pada kategori cukup baik dimungkinkan karena saat membimbing siswa dalam membuat rangkuman guru kurang memberi arahan. Pada aspek menyimpulkan materi juga ada dalam kategori cukup baik saja dimungkinkan guru langsung memberikan poin-poinya kepada siswa tanpa menanyakan bagaimana kesimpulan yang dibuat . Sesuai dengan pendapat Borich (1994:25) yang mendukung hal ini, penilaian instrumen dikategorikan baik dan dapat digunakan untuk kegiatan pengamatan apabila reliabilitasnya $275 \%$. Adapun reliabilitas instrumen kemampuan pengelolaan pembelajaran untuk uji coba pada pertemuan I, memperoleh skor $79 \%$, pada pertemuan 2 memperoleh skor $89 \%$, dan untuk pertemuan 3 memperoleh skor $79 \%$. Kesimpulannya bahwa instrumen pengamatan kemampuan pengelolaan pembelajaran yang digunakan dalam penelitian ini, termasuk dalam kategori baik, dan layak digunakan dalam proses pembelajaran

2. Aktivitas Siswa

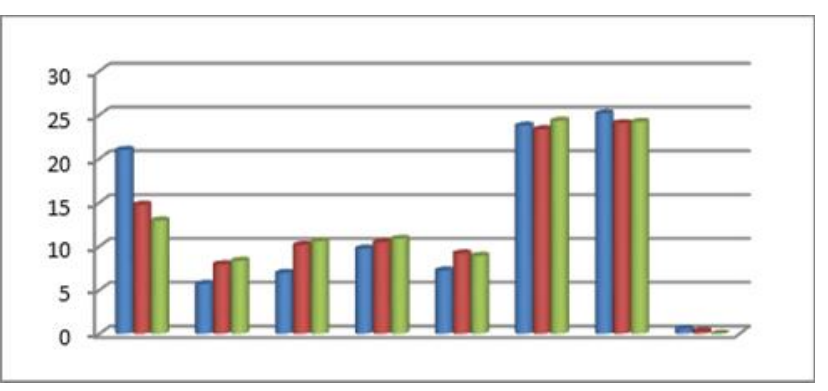

Grafik 4.7 Aktivitas Siswa

Penelitian ini menggunakan LKS bercirikan Guided discovery, sedangkan materi ditampilkan dengan Macromedia flash melalui model pembelajaran langsung. Ramadhian (2012), dalam jurnal Automotive Science and Education menyatakan bahwa, pembelajaran menggunakan metode ceramah dengan bantuan animasi dapat meningkatkan hasil belajar siswa, dibandingkan dengan pembelajaran yang hanya menggunakan metode ceramah saja.

Gagne (1992), menyatakan bahwa belajar merupakan kegiatan yang kompleks, hasil belajar berupa kapabilitas. Setelah belajar orang memiliki ketrampilan, pengetahuan, sikap, dan nilai. Timbulnya kapabilitas tersebut karena: (1) stimulasi yang berasal dari lingkungan, dan (2) proses kognitif yang dilakukan pembelajar. Belajar adalah seperangkat proses kognitif yang mengubah sifat stimulasi lingkungan, melewati pengolahan informasi menjadi kapabilitas baru.

Menurut Mulyasa (2002:108), aktivitas dan kreativitas peserta didik dalam belajar sangat bergantung pada aktivitas dan kreativitas guru, dalam menciptakan lingkungan belajar yang kondusif. Selain membangkitkan motivasi dan minat siswa, sumber belajar juga dapat membantu siswa meningkatkan pemahaman, menyajikan data dengan menarik serta terpercaya, memudahkan penafsiran data dan memadatkan informasi (Arsyad, 2006:16).

Minat dan perhatian dapat menjadi sumber motivasi, sebaliknya motivasi dapat menimbulkan minat dan perhatian. Hasil penelitian berkaitan dengan pengamatan frekuensi aktivitas siswa, selama proses pembelajaran pada penerapan perangkat pembelajaran langsung dilakukan oleh dua orang pengamat. Aktivitas siswa yang diamati yaitu: (1) Memperhatikan penjelasan guru melalui media Macro flash, (2) Mengajukan, menjawab, atau menanggapi pertanyaan dari guru, (3) Terlibat dalam Praktikum, (4) Berdiskusi antar siswa/guru, (5) Membaca bahan ajar siswa, (6) Menghormati pendapat orang lain, 
(7) Aktif mengerjakan LKS bercirikan Guided discovery, dan 8) Aktivitas yang tidak relevan. Berdasarkan Tabel 4.7 terlihat bahwa frekuensi aktivitas siswa yang paling dominan selama proses pembelajaran adalah mengerjakan LKS bercirikan Guided discovery mencapai rata-rata $25.74 \%$, dan terlibat dalam praktikum sebesar $23.33 \%$. Disusul kemudian pada aspek mendengarkan penjelasan guru melalui tampilan Macro flash sebesar $11.94 \%$. Kegiatan yang lain seperti mengajukan, menjawab, atau menanggapi pertanyaan dari guru, membaca bahan ajar siswa, menghormati pendapat orang lain rata-rata sebesar 9\%. Aktivitas tidak relevan juga muncul tetapi tidak besar hanya $0,28 \%$.

Aktivitas yang paling dominan pada saat proses pembelajaran, adalah mengerjakan Lembar Kerja Siswa bercirikan Guided discovery dan terlibat praktikum, hal ini wajar karena setelah mereka mengamati peristiwa yang terjadi saat praktikum berlangsung, mereka akan mengingat dan dikaitkan dalam menjawab pertanyaan yang ada. Kegiatan mendengarkan penjelasan guru melalui tampilan Macromedia Flash juga tinggi karena pembelajaran dengan menggunakan Macromedia Flash menarik minat para siswa. Sodikin (2009) mengatakan bahwa, siswa berperan lebih aktif dalam pembelajaran yang menggunakan sistem multimedia. Sejalan dengan yang dikemukakan Jamalludin (2003), kelebihan animasi dalam pendidikan: (1) animasi mampu menyampaikan konsep yang kompleks secara visual dan dinamik; (2) animasi digital mampu menarik perhatian pelajar dengan mudah; (3) animasi menyediakan pembelajaran secara maya; (4) animasi membuat pembelajaran manjadi lebih berkesan, menarik perhatian, serta meningkatkan motivasi. Didukung juga oleh pendapat Mulyasa (2002:216), proses pembelajaran pada hakekatnya untuk mengembangkan aktivitas dan kreativitas siswa, melalui berbagai interaksi, pengamatan, dan pengalaman belajar.

Pembelajaran melalui Macromedia Flash yang diajarkan dengan model pembelajaran langsung ditambah kegiatan praktikum dengan Lembar Kerja Siswa bercirikan Guided discovery menjadikan siswa lebih aktif. Keaktifan yang muncul termasuk dalam hal siswa dapat belajar materi yang mereka rasakan sulit secara animasi dan juga praktikum hingga paham. Keaktifan bertanya karena tertarik dengan pembelajaran, juga dapat berkontribusi terhadap peningkatan prestasi belajar siswa (Hendarto, 2012).

\section{Respon Siswa Terhadap Pembelajaran}

\begin{tabular}{|c|c|c|c|c|}
\hline \multirow{2}{*}{ No } & \multirow{2}{*}{ Uraian Pertanyaan } & \multicolumn{3}{|c|}{ Rata-rata Penilaian/Pendapat (\%) } \\
\hline & & Menarik & $\begin{array}{c}\text { Kurang } \\
\text { Menarik }\end{array}$ & $\begin{array}{c}\text { Tidak } \\
\text { Menarik }\end{array}$ \\
\hline 1. & Materi/isi pelajaran & 93 & 3 & 3 \\
\hline 2. & $\begin{array}{c}\text { Media } \\
\text { Pembelajaran }\end{array}$ & 97 & 3 & 0 \\
\hline
\end{tabular}

\begin{tabular}{|c|c|c|c|c|}
\hline \multirow{2}{*}{ No } & \multirow{2}{*}{ Uraian Pertanyaan } & \multicolumn{3}{|c|}{ Rata-rata Penilaian/Pendapat (\%) } \\
\hline & & Menarik & Kurang & $\begin{array}{c}\text { Tidak } \\
\text { Menarik }\end{array}$ \\
\hline 3. & $\begin{array}{l}\text { Format Lembar } \\
\text { kegiatan siswa } \\
\text { (LKS) }\end{array}$ & 80 & 20 & 0 \\
\hline 4. & Suasana belajar & 50 & 50 & 0 \\
\hline 5. & Cara mengajar guru & 93 & 7 & 0 \\
\hline \multirow[b]{2}{*}{ No } & \multirow[b]{2}{*}{ Uraian Pertanyaan } & \multicolumn{3}{|c|}{ Rata-rata Penilaian/Pendapat $(\%)$} \\
\hline & & Menarik & $\begin{array}{l}\text { Kurang } \\
\text { Menarik }\end{array}$ & $\begin{array}{c}\text { Tidak } \\
\text { Menarik }\end{array}$ \\
\hline 1. & $\begin{array}{l}\text { Bahasa pada media dan } \\
\text { bahan ajar pembelajaran }\end{array}$ & 97 & 3 & 3 \\
\hline 2. & $\begin{array}{l}\text { Materi pada media } \\
\text { pembelajaran }\end{array}$ & 87 & 10 & 3 \\
\hline 3. & $\begin{array}{l}\text { Bimbingan guru pada saat } \\
\text { mengerjakan LKS selama } \\
\text { kegiatan berlangsung }\end{array}$ & 93 & 7 & 0 \\
\hline 4. & $\begin{array}{l}\text { Cara penjelasan guru pada } \\
\text { saat kegiatan berlangsung }\end{array}$ & 87 & 13 & 0 \\
\hline
\end{tabular}

Bakrowi (2007) menyatakan bahwa siswa menyukai animasi-animasi yang digunakan guru untuk mengkonkritkan pembelajaran. Tidak berbeda adanya hasil analisis data respon siswa terhadap pembelajaran dapat dilihat pada Tabel 4.8, menunjukkan respon 30 siswa terhadap perangkat pembelajaran berbasis Macromedia Flash, secara umum pada aspek ketertarikan materi/isi pelajaran mencapai 97\%. Disusul 93\% siswa merasa cara mengajar guru dan materi yang disampaikan menarik. Hanya satu orang saja (3\%) yang menyatakan kurang menarik/tidak menarik terhadap materi pelajaran, media pelajaran, bahasa pada media dan bahan ajar, serta matari yang diberikan. Hal ini terjadi mungkin karena pendapat pribadi yang berlainan dengan pendapat mayoritas siswa dalam kelas. Sebanyak tiga orang siswa berpendapat materi yang diberikan kurang jelas, ini berkaitan dengan nilai siswa tersebut yang ternyata memang di bawah rata-rata kelas.

Empat orang siswa menyatakan penjelasan guru pada saat pembelajaran kurang jelas, disini mereka merasa lebih menarik dan jelas jika materi divisualisasikan melalui tampilan flash. Penjelasan guru dan bimbingan guru kurang maksimal juga imbas dari kelas yang kurang kondusif suasananya karena menggunakan ruangan laboratorium sebagai kelas pengganti. Untuk format Lembar Kerja Siswa sendiri $80 \%$ siswa menyatakan menarik. Terhadap suasana kelas $50 \%$ siswa menyatakan kurang menarik. Hal ini dikarenakan kelas mereka sedang mengalami renovasi, sehingga mereka menempati laboratorium yang suhunya cukup panas di lantai dua.

Berdasarkan hasil analisis respon siswa, maka dapat dikatakan respon siswa cukup positif terhadap perangkat 
serta kegiatan pembelajaran. Pernyataan ini tampak dalam hasil angket jawaban siswa terhadap komponen kegiatan belajar mengajar. Bahasa dirasa sudah jelas oleh siswa (97\%). Siswa (93\%) berpendapat bimbingan guru sudah jelas pada saat mengerjakan Lembar Kerja Siswa bercirikan Guided discovery, selain itu $87 \%$ siswa berpendapat materi yang disampaikan sudah jelas. Hasil respon siswa (Tabel 4.8), menunjukkan respon siswa sangat positif, karena proses pembelajaran yang dilaksanakan menggunakan perangkat yang telah dipersiapkan dengan baik dan menarik. Persiapan RPP, penggunaan Macromedia Flash, penggunaan LKS bercirikan Guided discovery, sintaks pembelajaran langsung, sangatlah mempengaruhi respon siswa. Berarti perangkat pembelajaran yang telah dikembangkan dapat mengenai sasaran, dan bahkan dapat meningkatkan minat siswa terhadap materi pelajaran khususnya mata pelajaran biologi, pokok bahasan proses perolehan nutrisi dan transformasi energi pada tumbuhan hijau di SMPN 22 Surabaya.

Tidak hanya pada penelitian ini saja yang mendapat respon baik dari siswa, Hasrul (2011) dalam jurnal MEDTEK juga mengemukakan bahwa mahasiswa Teknik Elektro Universitas Negeri Makasar, memiliki pandangan positif terhadap media pembelajaran dengan menggunakan aplikasi Macromedia Flash, pada mata kuliah instalasi listrik. Respon siswa yang baik pada pembelajaran menggunakan media Macro flash didukung oleh pendapat Beccue (2001), bahwa siswa dalam pembelajaran menggunakan multimedia menguntungkan siswa, siswa juga dapat mengulang meteri pembelajaran sesuai dengan keinginanya. Respon positif siswa sejalan dengan pendapat Dale (1969), yang mengklasifikasikan media berdasarkan pengalaman peserta didik, yaitu yang bersifat konkret ke abstrak meliputi sepuluh tingkat yaitu: (1) penglaaman langsung; (2) pengalaman melalui model; (3) dramatisasi; (4) demonstrasi; (5) karya wisata; (6) pameran; (7) televisi dan gambar hidup; (8) gambar diam dan rekaman radio; (9) lambang visual; (10) lambang kata. Dikaitkan dengan pendapat Dale (1969) tersebut, maka penggunaan media animasi Macro flash dapat dikelompokkan pada tingkat tujuh yaitu televisi dan gambar hidup. Media ini lebih konkret daripada media gambar diam, lambang visual, dan lambang kata. Hal ini didukung dengan pendapat Heinich (1996) yang menyatakan bahwa media pembelajaran dapat mengkonkretkan ide-ide atau gagasan yang bersifat konseptual, sehingga mengurangi kesalahpahaman siswa dalam mempelajarinya dan menjadikan siswa tergugah untuk belajar

\section{Hasil Belajar Siswa}

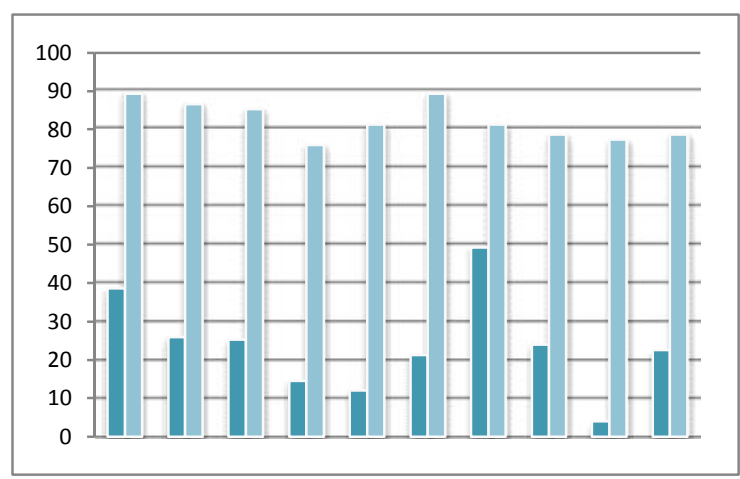

Grafik 4.9 Peningkatan Hasil Belajar

Macaulay (2003), menyatakan pengaruh positif multimedia yang membawa peningkatan nilai secara signifikan, pada siswa yang mengguanakan aplikasi multimedia dalam pembelajaran. Menurut teori Vygotsky, peningkatan hasil belajar tidak terlepas dari peran guru dalam memotivasi siswa sehingga tercipta lingkungan yang efektif. Tes hasil belajar produk merupakan tes hasil belajar siswa dari aktivitas kognitif berdasarkan proses mengetahui, memahami, berfikir, mempertimbangkan, membandingkan, memilih dan semuanya dalam keadaan sadar.

Hasil belajar siswa adalah tingkat peningkatan yang diperoleh siswa terhadap pencapaian tujuan pembelajaran atau indikator. Peningkatan hasil belajar diukur dari pemberian tes hasil belajar. Tes hasil belajar siswa dalam penelitian ini yang lebih dapat diketahui secara terukur adalah tes hasil belajar produk kognitif, karena tujuan pembelajaran atau indikator yang ingin dicapai termasuk dalam wilayah ranah kognitif.

Hasil belajar siswa pada aspek produk kognitif di atas, ditentukan berdasarkan hasil yang diperoleh dari tes hasil belajar, dengan berupa tes produk, dan yang digunakan dalam penelitian ini adalah tes tertulis pilihan ganda dan uraian dengan jumlah total 25 soal. Uji hasil belajar siswa dilakukan dua kali yaitu pretest dan postest. Pretest dilakukan sebelum guru menjelaskan materi pelajaran kepada siswa, yang digunakan untuk mengetahui kemampuan awal siswa. Postest diberikan kepada siswa setelah proses pembelajaran selesai selama tiga kali pertemuan. Postest digunakan untuk mengetahui, seberapa jauh siswa dapat menguasai materi yang telah disampaikan. Tes hasil belajar ini digunakan untuk mengetahui pencapaian peningkatan hasil belajar siswa.

Peningkatan hasil belajar siswa (Grafik 4.9), terlihat bahwa sebelum perlakuan semua siswa pada uji coba nilainya dinyatakan rendah, setelah diberikan perlakuan $100 \%$ meningkat hasil belajarnya. Nilai Pretest terendah pada siswa adalah 2.7 dan tertinggi 41.3. Nilai Postest terendah adalah sebesar 34.7 dan tertinggi adalah 94.7. Nilai semua siswa meningkat pada pelaksanaan Postest, 
meskipun kategori peningkatanya yang dihitung melalui gain score tidak semuanya tinggi. Peningkatan hasil belajar pada penelitian ini tidak lepas dari penggunaan Lembar Kerja Siswa yang bercirikan Guided discovery beserta kegiatan praktikumya yang disukai siswa dan tampilan Macromedia Flash, karena sebelum perlakuan pada pretes hasil belajar siswa rendah hanya mencapai nilai rata-rata di bawah 42 , setelah pembelajaran diberi perlakuan dengan menggunakan Macromedia Flash, hasil belajar siswa dapat meningkat dan mencapai rata-rata di atas 75 .

Hasil penelitian ini senada dengan yang dikatakan Widigdo (2012) dalam jurnal Automotive Science and Education, bahwa penerapan media pembelajaran berbasis Macromedia flash pada mata kuliah pompa dan kompresor di UNNES efektif meningkatkan hasil belajar. Penelitian Nugroho (2009) berkaitan dengan pengembangan multimedia pembelajaran, juga menunjukan kenaikan hasil belajar sebesar $30 \%$.

Hasil penelitian O'day (2007), menyatakan hasil positif pembelajaran menggunakaan media animasi ini yang menyediakan suatu cara, untuk berkomunikasi yang melibatkan urutan kompleks secara jelas dan efisien. Stith (2004) mengemukakan bahwa penggunaan animasi dan simulasi akan berdampak dalam peningkatan belajar. Sofyan (2010) mengemukakan bahwa terdapat interaksi pengaruh positif penggunaan media pembelajaran untuk motivasi belajar terhadap hasil belajar.

Sankar (2010) bersama rekan-rekanya menyajikan hasil penelitian yang dimuat dalam jurnal STEM, bahwa pembelajaran berbasis multimedia dapat memudahkan siswa dalam memahami materi, karena dapat menghadirkan kejadian-kejadian alam secara nyata di dalam kelas. Demikian pula penelitian Sunyoto (2006), yang mengemukakan bila seseorang terus menerus melihat dan mengamati suatu objek/gambar bergerak dengan penyajian yang menarik, maka dapat dipastikan seseorang akan termotivasi untuk memperhatikan dan mempelajarinya sehingga yang bersangkutan akan memahami konsep materi yang berpengaruh terhadap prestasi belajar. Dari hasil penelitian Armani (2005), dikatakan bahwa Macromedia flash dapat memperkuat tampilan visual dalam berbagai komponen, serta mampu untuk memenuhi kebutuhan penyajian yang lebih menarik

\section{SIMPULAN}

Temuan-temuan pada penelitian kali ini antara lain:

1. Hasil validitas perangkat pembelajaran yang dikembangkan adalah layak untuk digunakan.

2. Keterlaksanaan kegiatan pembelajaran masuk pada kategori baik.

3. Respon siswa sebagian besar menyatakan kegiatan pembelajaran menarik untuk diikuti.
4. Aktivitas siswa saat mengikuti pembelajaran tinggi pada kegiatan memperhatikan Macromedia flash dan pelaksanaan praktikum.

5. Hasil belajar delapan puluh persen siswa di kelas meningkat setelah mengikuti kegiatan pembelajaran

Berdasarkan temuan seperti yang telah dituliskan, dapat dirumuskan simpulan sebagai berikut: Perangkat pembelajaran yang dikembangkan efektif dalam meningkatkan hasil belajar siswa di SMP.

\section{DAFTAR PUSTAKA}

Arends, R.I. 2007. Learning To Teach. New York: McGraw Hill Companies.

Armani, J. 2005. VIDET: a Visual Authoring Tool for Adaptive Website Tailored to Non-Programmer Teachers. Journal Educational Technology \& society [online]. 8. (3). 36-52.

Arsyad, A. 2006. Media Pembelajaran. Jakarta: PT.Raya Grafindo Persada.

Bakrowi. 2007. Microsoft Officer Power Point sebagai Media Pembelajaran Materi Unsur, Senyawa, dan Campuran Berbasis STAD. Jurnal Pendidikan Inovatif [online]. Volume 3. Nomor 1

Borich, G.D. 1994. Observation Skills for Effective Teaching. New York: Macmillan Publishing Company

Beccue, B., \& Vila, J. 2001. The Effects of Adding Audio Instructions to a Multimedia Computer Based Training Enviroment. Journal of Educational Multimedia and Hypermedia [online]. 10 (1). 47-67

Dale, E. 1969. Teori-Teori Belajar. Jakarta: P2LPTK.

Gagné, R.M, Briggs, I.J \& Wager, W.W. 1992. The Conditions of Learning $3^{\text {rd }}$ Edition. Japan: HoltSaunders International Edition Publishers

Hasrul. 2011. Desain Media Pembelajaran Animasi Berbasis Adobe Flash CS3 Pada Mata Kuliah Instalasi Listrik 2. Jurnal MEDTEK [online]. Vol.3. No. 2

Hendarto, S., Sunyoto., \& Aryadi, W. 2012. Penggunaan Video Animasi Untuk Meningkatkan Prestasi Belajar Siswa Dalam Pembelajaran Kompetensi Sistem Starter. Automotive Scinece and Education Journal [online]. 1. 1. 38-43.

Jamalludin, H., \& Zaidatun, T. 2003. Multimedia Dalam Pendidikan. Bentong: PTS Publication

Mulyasa, E. 2002. Kurikulum Berbasis Kompetensi. Bandung: Rosdakarya

Nugroho., \& Agustinus, H. 2009. Pengembangan Multimedia Pembelajaran Untuk Peningkatan Kualitas Pembelajaran Mata Kuliah Akuntasi. Tesis. Yogyakarta: Program Pascasarjana Universitas Negeri Yogyakarta 
Nur, M. 2008a. Pengajaran Berpusat Kepada Siswa dan Pendekatan Konstruktivis Dalam Pengajaran: Edisi 5. Surabaya: PSMS Universitas Negeri Surabaya

O'day, D.H. 2007. The Value of Animations in Biology Teaching: A Study of Long Term Memory Retention. A Journal of Lefe Science Education [online]. 6.3.217-223

Sagala, S. 2008. Konsep dan Makna Pembelajaran.Bandung: CV. ALFABETA

Sodikin., Noersasongko, E., \& Pramudi, T. 2009. Jurnal Penyesuaian Dengan Modus Pembelajaran Untuk Siswa SMK Kelas X. Jurnal Teknologi Informasi [online]. Volume 5. Nomor 2.

Sofyan, A. 2010. Implementasi CD Animasi Pendidikan Indonesia Untuk Meningkatkan Kualitas Pembelajaran Sains Siswa Kelas V SD Negeri Catur
Tunggal 04. Tesis. Yogyakarta: Program Pascasarjana Universitas Negeri Yogyakarta

Stith, B.J. 2004. Use of Animation in Teaching Cell Biology. A Journal of Life Science Education [online]. 3.3.181-188.

Sunyoto. 2006. Efektivitas Penggunaan Modul Pembelajaran Interaktif Untuk Meningkatkan Prestasi Belajar Siswa SMK Bidang Keahlian Teknik Mesin. Jurnal ATM [online]. 6,1.

Sutopo, A.H. 2003. Multimedia Interaktif dengan Flash. Yogyakarta: Graha Ilmu. 